\title{
Indigenous Culture: The Politics of Vulnerability and Survival
}

\author{
Tim Rowse
}

'Indigenous' is the problematic adjective in this chapter. The noun 'culture' I am not so worried about. For the sake of starting somewhere, I follow the argument by Helliwell and Hindess (1999) that 'culture' is a meaningful category in modem projects of government. Asking why the human sciences have been so committed to the idea that humanity can be understood as a number of different 'societies' (discrete, self-regulating) and 'cultures' (the ideational unity that makes a 'society' possible). they answered, in part, by pointing to the govemmental ambition to make populations productive.

It is the imaginary realization of this desire to harness society's resources that presents us with the fantastic image of society itself as a discrete, self-regulating unity that incorporates civil society, culture, economic activity and morality as 50 many component parts of one systematic whole-and it is this sense of systemic totality that suggests radical difference between members of distinct societies. (He!liwell and Hindess, 1999: p. 14)
The notion 'Indigenous culture', I will argue. enables us to think about the relevance to government of a radical difference between members of distinct societies' - a difference in susceptibility to those changes that we call 'development'. In the language of development studies, the notion 'Indigenous culture' has been liberally and potently present through the currency of the phrase 'Indigenous knowledge'. I will begin this chapter by reporting a recent debate about the pertinence of 'Indigenous knowledge' to 'development. Working back from the modem govermmental project 'development', I will trace two ideas that emerged within Imperial sensibility once it began to make cultural difference a matter of ethical consequence: a concern for the 'vulnerability' and for the 'mmanent temporality' of non-European peoples. By a brief examination of the work of the International Labour Office (LO) I will argue that notions of 'vulnerability" and 'immanent temporality' have been formative 
of the late-twentieth-century recognition of the Indigenous'. In the second half of this chapter, I will illustrate the richness of the idea of 'vulnerability' by reading some recent academic commentaries on contemporary Indigenous peoples in the Anglophone settlercolonies.

\section{IS THERE SUCH A THING AS 'NDIGENOUS KNOWLEDGE'?}

Michael Warren, a social scientist studying 'development', told readers of the Indigenous Knowledge and Development Monitor in 1996 how he and his colleagues had come up with the phrase 'Indigenous knowledge'. They did not like the connotations of "traditional knowledge" because "traditional" denoted the nineteenth-century attitudes of simple, savage and static. We wanted a term that represented the dynamic contributions of any community to problem solving, based on their own perceptions and conceptions, and the ways that they identified, categorized and classified phenomena important to them' (Warren, 1996). This coinage led not only to the inception of the journal in which Warren was writing, but also to " 25 indigenous knowledge resource centres scattered across countries in Africa, Asia, Europe, Latin America, Middle East, and North America' (Agrawal, 2002: p. 288).

Warren was responding to Agrawal's objections (Agrawal, 1995) that 'Western knowledge' and 'Indigenous knowledge' are Internally heterogeneous categories, and that they had been in contact and exchange (however unequal) for five centuries. Citing recent philosophy and sociology of science, Agrawal had argued that there are no substantive, methodological or epistemological criteria to distinguish knowledge that is 'Indigenous'. Warren's and other's' responses to Agrawal reafirmed the category 'Indigenous knowledge'.

Some emphasized the localness of 'Indigenous knowledge': 'Indigenous knowledge is the practical knowledge and experience of people who still have a direct link to the "soil" and their immediate environment' (Köhler-Rollefson, 1996). Another argued that the localness of Indigenous knowledge usually meant that it was obtainable outside the market or in local markets that did not depend on currency, unlike "scientific knowledge', which often had a price tag; it was associated with techniques of production that had not yet been converted to the forms of contemporary agribusiness (van 't Hooft, 1996). 'Local expertise' was central to 'Indigenous knowledge': 'It makes perfect sense for me as an educator to distinguish Indigenous knowledge as a category when examining educational systems as pedagogical sites of knowledge production. This category is made possible by identifying the producers of knowledge as distinct actors' (Semali, 1996). The localness of 'Indigenous knowledge' obviated the perilous process of technology transfer (Hess, 1996). From the point of view of locals such as Andean peasant farmers, it was easy to distinguish 'indigenous and scientific/Western knowledge', wrote two US anthropologists (evidently without understanding Agrawal's argument that no general characterization of the difference was possible) (Benfer and Furbee, 1996).

Another ground for making the distinction, argued one Canadian respondent, was the motive for knowledge development. "The development of iatrobotanical knowledge by Canadian west coast Indigenous peoples (e.g. on Vancouver Island's Clayoquot Sound) is clearly motivated by "immediate and concrete necessities", while the development of certain aspects of knowledge concerned with particle physics by Canadian west coast scientists (at Vancouver's TRIUMF facilities) is not' (Heyd, 1996). Indigenous knowledge 'entails the honing of sensory skills that are not exercised in the course of academic study' (Köhler-Rollefson, 1996). Pertinence to practice was what commended 'Indigenous knowledge" to the Food and Agriculture Organization, one of its officers pointed out (Van Crowder, 1996).

Some authors pointed to the embedded, holistic character of Indigenous knowledge. The environment of Indigenous knowledge 
production was not a specialized facility but "the full context of lived experience" (Heyd, 1996). 'The local symbolic system' is 'an integral part' of Indigenous knowledge. wrote Giarelli, so Indigenous illness remedies could not be reduced to their active chemical components without extinguishing the contextual meaning that contributed to their therapeutic effect (Giarelli, 1996). Haverkort and Hiemstra have coined the term 'cosmovision' to refer to the symbolic systems of which agricultural practices are a part, in faming communities in India, Sri Lanka, Ghana, the Netherlands, Norway, Mexico, Peru and Bolivia (Haverkort and Hiemstra, 1996). Brouwer asserted that "the study of Indigenous knowledge is impossible without a knowledge of Indigenous languages' (Brouwer, 1996).

Several responses to Agrawal were politically self-conscious. The unfortunate tradition of imposing technologies, in the name of "development", made it desirable to uphold the local non-expert. If 'indigenous knowledge' is 'thetoric", then it is important rhetoric, insisted Semali "because it encourages a discussion that has been suppressed for many years by the dominant European-centred education systems' (Semali, 1996). One of the originators of the term described himself and his colleagues as "people with a mission to convert the "heathens", those who do not accept the value of Indigenous knowledge or its potential contribution to development. I held this view 30 years ago, and Agrawal has not persuaded me that I should change it now' (Brokensha, 1996).

In reply, Agrawal pointed to anthropological research that supported his scepticism (Ellen et al., 2000). He was still not persuaded that we can distinguish 'Indigenous lnowledge' as a kind of knowledge - local, embedded in context, holistic, and so on. However, he wanted to recover 'Indigenous knowledge' in political terms. 'The critical difference between indigenous and scientifc knowledge is not at an epistemological level: rather it lies in their relationship to power... the criterion of power will trimph when local, traditional, or practical knowledge is contrasted with global, modern, or theoretical knowledge" (Agrawal, 1996).

\section{CONSTTUTVE AGENTS}

If Indigenous knowledge was defined in terms of its vulnerability to marginalization by more powerful knowledge then it conld be found, or it could announce itself to be, anywhere. Thus Serrano suggested that 'indigenous knowledge systems and practices must exist among Westem cultures', and Köhler-Rollefson asked how we would classify 'the kitchen garden skills of Geman farm women'? (Serrano, 1996; Köhler-Rollesson. 1996). Much of the scholarly attention to 'Indigenous people' emphasizes their selfconstructive agency. Dean and Levi, theorizing indigeneity as a kind of ethicity. write:

An indigenous people become an ethnic group not simply by sharing such things as a group name (ethnonym), connection to horneland, and beliếs in common ancestry, culture, language, or religion, but only when such traits are consciously recognized as emblems of connectivity and are mobilized at least in part to develop a serise of political solidarity. (Dean and Levi, 2003)

However, note that the crucial verbs in this passage are passive: 'recognized' and 'mobilized'. Who is recognizing and mobilizing? The authors answer: "Typically, this occu's when such groups perceive their minority or submerged status within the polities where they reside' (Dean and Levi, 2003: p. 5).

This is not good enough: the constimtion of the category 'Indigenous' is an effect of actions by a number of different actors. In Yudice's account of the public performance of cultural difference in the USA, the clam to autonomy and legitimacy on the basis of a particular culture is made possible by the conjuncture of a welfare state that defines clients by group, by a media and market system that targets consmmers, by the juridical means available to challenge discrimination' (Yudice, 2003: p. 56). Amnt Muehlebach writes that 'difference . . camot simply be unilaterally claimed. It must be 
fought for and acknowledged by the actors and parties addressed' (Muehlebach, 2001: p. 419; emphasis added). The anthropology of Indigenous peoples, according to Kay Warren, no longer thinks of 'cultures as bounded entities and fixed authenticities' but focuses on 'culture makers' (Warren, 1998: p. 27) - a term that is open-ended. Her work on pan-Mayan activism includes discussing the class interests of a Mayan niddle class that, deploying pan-Mayanism as cultural capital', parallels and competes with Guatemala's Ladino-identified professionals Warren, 1998: pp. 49-51, 201-202). Tania Li argues that the factors enabling the Lindu people to articulate 'a collective position as Indigenous people' were:

competition for resources, in the context of which group boundaries were rendered explicit and cultural differences entrenched; the existence of a local political structure that included individuals (elders, leaders) and an adat council mandated to speak on behalf of the group; a capacity to present cultural identity and local knowledge in forms intelligible to outsiders - an activity undertaken in this case by a literate elite of teachers, local officials, prosperous farmers, and entrepreneurs; an nterest on the part of urban activists in discovering and supporting exemplary indigenous subjects, and documenting indigenous knowledge which fit the niche preconstituted in national and international environmental debates; and, finally, heightened interest in a particular place, arising from a conflict which pit locais against the state or state-sponsored corporations. (Li, 2000: p. 169)

Although we can't do without some people' whose claims to be Indigenous are in contention, I see no reason to grant theoretical priority to one kind of agent in the constitution of an 'Indigenous people'. One agent that we should not overlook is the World Bank.

\section{THE WORLD BANK AND INDIGENOUS CULTURE}

According to Craig Murphy, "development populism' is the global hegemonic ideology. While there may be a diversity of views about development' among multilateral, nationstate and non-govemment agencies, there tends to be unifomity of understandings of 'development' among officials 'on the ground' and their clients. At that level, development has come to refer to strengthening the public infrastructure of the Third World state and 'making their citizens more dependent on the central authorities for basic social services' (Murphy, 1994: p. 217). The post-WorldWar-II project of global 'development' has successfully shaped and appealed to popular material interests, incorporating "the Third World masses into the often disappointing political systems that they or their parents fought to create' (Murphy, 1994: p. 217). Murphy contrasts the relative uniformity of popular experience of 'development populism' with the plurality of perspectives found within the loosely integrated system of institutions that has evolved since the 1940 s to deliver 'development'. The UN agencies, relatively autonomous from one another, rely on institutions of international civil society and on the 'epistemic communities' - technical workers such as economists, engineers, doctors, anthropologists - that are associated (as clients, critics, consultants) with them. People and agencies within this loose-knit system have room to consider the multiple ends of development and to debate the trade-offs anong: economic growth, equality of distribution, environmental sustainability, bio-diversity, cultural diversity.

While diverse agencies and peoples may weight these goals differently, 'development' is unlikely not to refer to changes in the processes of production of goods and services, including changes in the means of transport and communication. A debate about the manner and content of 'development' acknowledges that it is possible to be variably suited to such changes, and even to be vulnerable to them. In what ways could 'development' be bad for people? The World Bank's answer to that question is implied in a 1991 'operational directive' that lists the characteristics of 'the Indigenous'.

In quoting them (World Bank, 1991: n.p.), I have interpolated in italics the implied vulnerability. 
(a) a close attachment to ancestral territories and to the natural resources of these areas; with 'development' they might have to change their use of these resources or even to lose their occupation and use of them.

(b) self-identification by others as members of a distinct cultural group; 'development' might compel them to transact with strangers whose ways are embarrassing, puzzling or threatening to that acknowledged distinctness.

(c) an Indigenous language, often different from the national language; they might have to accommodate new terms into their language, or learn a new language, in order to transact, and they may reasonably fear for the survival of their language.

(d) presence of customary social and political institutions; these institutions may be inhospitable to new transactions and relationships and thus may be abolished/reformed, may fall into disuse, or may lose their centrality to collective identity.

(e) primarily subsistence-oriented production; almost certainly, production will be redirected towards exchange, and labour power will become a commodity.

In these ways, 'development' is a process from which people might seek protection, or special consideration by "developing" authority. To be deemed 'Indigenous' is to have one's vulnerability to development acknowledged and to be entitled (in principle) to consideration from the World Bank or from agencies over which it has influence.

The World Bank in 1991 said that in 'any project that affects indigenous peoples and their rights to natural and economic resources' it is essential to get 'the informed participation of the indigenous peoples themselves ... through direct consultation, incorporation of indigenous knowledge into project approaches, and appropriate early use of experienced specialists... '(World Bank, 1991: n.p.). That the World Bank can be pressured to dishonour these standards became evident in the 1990 s when the Pehuenche people were not allowed by the International Finance Corporation (the private sector arm of the World Bank Group) to see an anthropologist consultant's report on the social impact of the Chilean government's Pangue Dam (Johnston and Garcia-Downing,
2003). To the extent that the World Bank can be embarrassed by a national govermments bullying of Indigenous people (as it was by Chile), the Bank has an interest in monitoring domestic policies towards any peoples that claim (or that might claim) the status 'Indigenous'; the Bank seeks 'Bank. country dialogue' on such issues. The World Bank thus has the potential to be either an (embarrassed) accomplice or a critic of national governments accused of trampling upon Indigenous rights.

How have such leader's of global capitalism become susceptible to the argument that 'development' must confer what the Bank calls 'culturally compatible social and economic benefits' (World Bank, 1991: n.p.; my emphasis)? How did the European colonial project come to treat cultural difference as relevant in this way?

\section{ENLIGHTENMENT CRITICS OF EUROPEAN UNIVERSALISM}

In his distinctive characterization of 'modernity', Charles Taylor (2004) represents it as a moral order whose intellectual lineage can be traced back to the detaching of human affars from divine authority that natural law theorists Hugo Grotius and John Locke initiated in the seventeenth century. Through numerous 'redactions' since then, the idea that humanity contrives its own political and moral order for its own quotidian good has been extended in scope and intensity so that it now makes up a 'social imaginary' whose four 'crucial features' are:

(1) the order of mutual benefit holds between individuals (or at least moral agents who are independent of larger hierarchical orders); (2) the benefits crucially include life and the means to life. although securing these relates to the practice of virtue: ... (3) the order is meant to secure freedom and easily finds expression in terms of rights... (4) these rights, this freedom, this mutual benefit is to be secured to all participants equally. Exactly what is meant by equality will vary, but that it must be affirmed in some form follows from the rejection of hierarchical order. (Taylor, 2004: pp. 23-22) 
d Bank can vernment's (as it was interest in wards any claim) the ks 'Bank The World be either a critic of trampling

capitalism ment that the Bank and eco: in.p.; my colonial erence as

'moder-

ats it as a ye can be in affairs theorists tiated in umerous umanity al order xtended makes "crucial
Sankar Muthu has recently described one 'redaction' of these ideas that was stimulated by two centuries' record about the best and worst of European conduct in the New world: the critique of 'empire' offered by Kant, Diderot and Herder. Muthu sees three inportant ideas in the Enlightenment critique of European colonization. One was that as humans, the colonized were entitled to respect. Second, and more innovatively, the critique conceived humans as 'fundamentally cultural beings or cultural agents ... as artful, reasoned, and free individuals who are partly shaped by their social and cultural contexts, vet who also through their actions and through changing perceptions alter such contexts themselves' (Muthu, 2003: p. 274). The third step is what makes anti-imperial Enlightenment thought such a singular episode in European history. In Herder's words 'the culture of man is not the culture of the European; it manifests itself according to place and time in every people' (quoted in Muthu, 2003: p. 276).

Muthu sadly notes, however, that Enlightenment-era anti-imperialist thought falled to generate a legacy that would be nurtured by prominent nineteenth-century thinkers' (Muthu, 2003: p. 278). A famous critique of imperialism published at the end of the nineteenth century, J.A. Hobson's Imperialism: A Study (1902) pleads not for the cessation of inperialism but for European colonists to set higher standards for colonial conduct. Governments could combine forces to protect the natives from colonial adventurers and from the more predatory nations. '[F]or the real good of the subject race' (Hobson, 1938: p. 235), Hobson proposed that development not be mposed but solicited; it must be immanent of place and of people: 'to step in and utilize natural resources which are left undeveloped is one thing, to compel the inhabitants to develop them is another' (Hobson, 1938: p. 28). He decried policies that induce or compel natives to substitute wage labour ... for the ancient tribal life upon the land' (Hobson, 1938: p. 259). 'If under the gradual teaching of industrial arts and the general educational influences of a white protectorate many of the old political, social and religious institutions decay, that decay will be a natural wholesome process, and will be attended by the growth of new forms, not forced upon them, but growing out of the old forms and conforming to laws of natural growth in order to adapt native life to a changed environment' (Hobson, 1938: p. 280). In the words 'natural' and 'tropical' Hobson evoked the immanence of the development to which colonized peoples were entitled: 'Natural growth in self-govemment and industry along tropical lines would be the end to which the enlightened policy of civilized assistance would address itself' (Hobson, 1938: p. 243).

Imperialists in the nineteenth century had not been able to ignore the practical demands of the fact that humans are fundamentally, and in different ways, cultural beings or cultural agents, and that each society carried in its own fashion the burden of a past. Evangelical Christianity, undoubtedly a form of imperial power, included the belief that the barbarians would be more disposed to receive divine grace if they found God's word in their own language. This was a Christian application of a broader humanism nurtured by studies of the languages of the New World. From the late eighteenth century English Protestant missionaries undertook an immense project of Bible translation. In one theory of Christian mission, the word 'Indigenous' came to signify, honourably, the different ways that non-Europeans were embracing Christianity. Thus Henry Vem (1796-1883), Honorary Secretary of the Church Missionary Society, envisaged the 'euthanasia' of the European clergy in Africa, India and even in parts of the Antipodes, to make way for an 'Indigenous' Christian church. The native clergy would not have to master Latin, Greek and sophisticated theology; "simple vernacular training, preserving native dress and life style' would free the Gospel from its metropolitan encumbrance (Williams, 1990: pp. 19-20). 'Native Bishops' would embody an ecclesiastical authority attuned to local traditions. 'Association' between metropolitan and native churches, not "superintendence' 
or 'dependency', was the political ideal of these architects of mission.

India was a tutor to imperial pretensions, as we can see from the work of Henry Maine, Legal Member of the Council of the Governor-General of India from 1862 to 1869. In 1857 , British authority in India had been shocked by the Indian Mutiny into making a more critical appraisal of the nature and limits of colonial authority. Drawing on his experience of governing post-Mutiny India, Maine became an infuential interpreter of Indian society. In a chapter that he published in 1887, Maine argued that the biggest challenge in governing India was to reconcile two temporalities. A minority of Indians was committed to one temporality: these people were seized with the urgency of progressing India towards modem ways. The majority of Indians, however, was still entangled in what Maine called 'a dense and dark vegetation of primitive opinion, stubbornly rooted in the debris of the past' (Johnson, 2004: p. 73). Those governing India had the difficult task of respecting both the forward-looking minority and the immobile majority. "If they are too slow, there will be no improvement; if they are too fast, there will be no security", wrote Maine (quoted by Johmson, 2004: p. 73).

This 'too slow'/ too fast' dilemma is one of the defining issues of the enlightened approach to colonial trusteeship that flourished in the twentieth century.

\section{THE LEAGUE OF NATIONS}

Hobson's ideas contributed to a movement among British intellectuals in World War I to remove "natives" from the responsibility of nation-states and to entrust them to an international body. The League of Nations, founded by the Treaty of Versailles in 1919, fell short of their schemes (Porter; 1990: pp. 178-179), but the League's 1920 Covenant was nonetheless the first formal recognition by the world's governments that there was a category of 'Indigenous people" entitled to special treatment because of their vulnerability. When the Covenant referred to
'Indigenous people', it was not all the 'native peoples' whose well-being Hobson had considered, but only those whose "vulnerability" took a form that weighed heavily on the European statesman's mind at that time: they were 'deprived', by the war, of a colonial
master.

That is, although liberal Imperialists such as Hobson would have liked all colonies to be intemationally mandated, the League mandated colonial authority only over those native peoples that had been under Ottoman and German authority. As 'peoples not yet able to stand by themselves under the strenuous conditions of the modern world' (Article 22), certain aggregations of humans could make a claim on the world's conscience, as the Covenant formulated it: 'The well-being and development of such peoples form a sacred trust of civilization" and "the tutelage of such peoples should be entrusted to advanced nations' (Article 22). Some peoples would require more careful supervision than others. according to 'the stage of the development of the people". Article 22 mentioned the 'communities' formerly governed by the Turkish Empire as among the more sophisticated. As well - and here we find the word 'Indigenous' - there were the inhabitants of the 'territories' in South West Africa and the South Pacific Islands. Under a " $\mathrm{C}$ " class mandate, the League entrusted South West Africans to South Africa, the people of the Marianas, Caroline and Marshall Islands to Japan, the peoples of New Guinea (northeastern part), New Ireland, New Britain and the Solomon Islands to Australia, the people of Nauru to the British Empire (to Australia. in effect) and the people of Westem Samoa to New Zealand. Peoples rendered vulnerable. not only by 'backwardness' but also by the loss of their colonial overlord, were the first to be labelled by a multilateral agreement as "Indigenous".

However, the League did not see these 'Indigenous' peoples as the only peoples who were owed a more considered tutelage. When the Intenational Labour Organization wrote Conventions to govern the well-being of the labourers of the world, it used the 
word 'Indigenous' to refer to a greater nunber of peoples than those who lived in the former German colonies of Africa and the Pacific. In three conventions that it published in the 1930s - the Recruiting of Indigenous Workers Convention (1936), the Contracts of Employment (Indigenous Workers) Convention (1939) and the Penal Sanctions (Indigenous Workers) Convention (1939) - the term 'Indigenous' included not only workers belonging to or assimilated to the Indigenous populations of the dependent teritories of Members of the Organization' but also "workers belonging to or assimilated to the dependent indigenous populations of the home territories of Members of the Organization' (Article 2b of each of the above three conventions, emphasis added). This broadened 'Indigenous' from those African and Pacific peoples who had lost their colonial overlord (Germany) as the result of the war to something closer to its current meanings.

What was 'Indigenous' labour, in this broader sense, understood to be? Here the important word seems to be 'native'. A guide to the ILO's work written for young people stated in 1937 how natives were tunderstood by the authors of ILO Conventions: "Whereas they were formerly regarded as lazy members of the human race, who were better for enforced regular employment, it is now realized that what seemed like laziness was sometimes the fact that they were fully occupied with their own economic affairs, sometimes malnutrition, and sometimes fundamental unsuitability for industrial work. Furthermore, the real potentialities of these people now begin to have some consideration. Their simple economy is beginning to be protected, their craftsmanship encouraged, and their codes of living given respect' (Gibberd, 1937: p. 83; emphasis added). It was assumed that to administer 'native labour' required a particular expertise that could see such labour in its social setting. "Native labour' was intelligible only in the context 'of tribal life, of health conditions, standards of living and habits of these workers, including in many cases those relating to marriage and tribal life' (ILO, 1931: p. 222).
Experts in native labour faced a riddle that is characteristic - as we now know of modern human rights discourse: how to respect custom while 'developing'. The problem, as conceived by the ILO, was to time modernity's challenges (and here is the echo of Maine's 'too slow'/ too fast' dilemma):

Legistation based on native custom may artificially cause to survive primitive forms of relations between employers and employed, while more advanced laws may bring the native, as yet unprepared for such changes, face to face with modern conceptions of the relationship between capital and labour from which he would be unable to profit. (ILO, 1931: p. 222)

Thus, a case could be made both against and for the ILO's submission of 'custom' to regulation. We can see in the wording of some Conventions in the 1930s the ILO considering carefully its approach to labour that was subject to customary obligation. In the Convention on Forced Labour (1930), Article 19 was about the possibility that 'compulsory cultivation' could be justified 'as a method of precaution against famine or a deficiency of food supplies' as long as the resulting food was shared among the cultivators. The Article also allowed to persist 'the obligation on members of a community, where production is organized on a communal basis by virtue of law or custom and where the produce or any profit accruing from the sale thereof remain the property of the community, to perform the work demanded by the community by virtue of law or custom'. Nine years later, the ILO seems to have edged closer to regulating 'custom'. The Penal Sanctions (Indigenous Workers) Convention (1939) sought to abolish penal sanctions on breaches of contract by employees. It applied to contracted (not customary) service (see Article 1(1)), but it explicitly included 'Indigenous' employers, whether they were paid in cash or 'in any other form whatsoever'. Whether this applied ILO standards of employment to all 'customary' labour; that had so recently been exempt from such standards in the Convention on Forced Labour, may have depended on what counted as a 'contract'. 
After World War II, the ILO became the main UN agency to speak authoritatively on the managed transformation of 'indigenous and other tribal and semi-tribal populations which are not vet integrated into the national community and whose social, economic or cultural situation hinders them from benefiting fully from the rights and advantages enjoyed by other elements of the population' (Indigenous and Tribal Populations Convention, 1957; emphasis added). The theme of this Convention (no. 107) was the supervision of uncoerced progress of certain vulnerable peoples towards the conditions of life common to the nation in which they found themselves. For example, Article 23 wanted govemment provision "for a progressive transition from the mother tongue or the vernacular language to the national language or to one of the official languages of the country' while, at the same time 'appropriate measures shall, as far as possible, be taken to preserve the mother tongue or the vernacular language:. Integration was good, but 'artificial assimilation' was proscribed (Article 2). Special measures of protection were good, as long as they did not last forever and did not create or prolong 'a state of segregation" (Article 3). A document of such ethical trade-offs, gesturing towards a timetable of change that could be neither doubted nor defined, left room for judgement about any nation-state's conduct towards 'Indigenous and tribal populations'.

The revised ILO Convention on Indigenous and Tilbal Peoples (1989, in force from September, 1991) enjoins that govermments will not make such judgements unilaterally; they must discuss them, in good faith, with the Indigenous and tribal peoples who are assumed to be not a passing but a permanent feature of the nation-state and to be capable, in their maintained or revived institutions, of such a dialogue. Indigenous organizations since 1975 have been elaborating, in international forums, the implications for nationstates of the arrival of "the Indigenous voice in world politics' as encoded in ILO 169 and in similar declarations (Wilmer, 1993; Niezen,
2003).
Thus the adjective 'Indigenous' - applied to nouns such as 'culture', 'society' and 'knowledge' - has become a 'keyword' in a way of imagining non-European history as a sympathetically managed transfomation. Notwithstanding that the ideas of protection. and preservation have gained force, and that Indigenous actors have registered inevocably that they will speak and act in their own interests, the assumed underlying reality remains 'transformation'. David Maybury-Lewis, one of the best-known advocates of respect for Indigenous peoples to have emerged during the 32 years that separate the two ILO Conventions, made this clear when he explained the name of the advocacy body that he helped to found, Cultural Survival. Cultural survival does not mean stasis, but cultural control and continuity. Such cultures can be said to survive (and are thought to do so by the people that live in them) to the extent that their members control their own affairs and maintain a satisfactory continuity with the past. Since no society, especially in these days when globalization proceeds apace, has complete control over its own affairs (and Indigenous societies, by definition, do not). cultural survival is always a relative matter" (Maybury-Lewis, 2003: p. 326).

In late-twentieth-century multilateral respect for the Indigenous, the old issue of enlightened colonial authority - what weight should be assigned to the customs of the colonized? - is handed to a new (or newly recognized) post-colonial subject. Increasingly, 'the people that live in them' are invited to judge whether the customs of their societies matter, and in what way they matter. to deliberated projects of social and cultural reproduction and transformation, that is, to government. The modern discourse of human rights and self-determination propagated since World War I by the wealthiest nations on earth has evolved a language for bestowing legitimacy on the demand that, in the name of their difference, Indigenous people should manage how (or whether) their labour and their land become commodities in a global system of exchange. "Indigenous people" is the key phrase for global organizations 
that have written standards for the exchange of labour power (the ILO) and for the flow of capital for 'development' (the World Bank).

As a multilateral keyword, 'Indigenous' is as difficult to define as it is politically attractive to use (Beteille, 1998; Bowen, 2000; Colchester, 2002; Dean and Levi, 2003: pp. 4-9; Kenrick and Lewis, 2004; Kingsbury, 1998; Kuper, 2003; McIntosh, 2002). When the Working Group on Indigenous Populations (WGIP) first convened at the UN in 1982 , there were 30 Indigenous and non-Indigenous participants; by 1999 the WGIP meeting was attended by 46 South and Central American indigenous groups, 40 Asian indigenous organizations, 31 US and Canadian indigenous organizations, 23 African indigenous organizations, nine Australian Aboriginal organizations, six Russian and Siberian indigenous organizations, five indigenous Pacific organizations, four Inuit indigenous groups, two Saami organizations, and about six explicitly: international indigenous organizations" (Muehlebach, 2001: p. 420). Ian McIntosh, former editor of Cultural Survival Quarterly, has reminded us that the potency of Indigenous' could dissipate from over-use (McIntosh, 2002: pp. 23-24).

\section{IFINDIGENOUS' IS THE ADIECTVE 'SURVIVE' IS THE VERB}

In the phrase 'cultural survival' is the word cultural" redundant, or are there forms of Indigenous survival that are not "cultural'?

If we try to think of Indigenous being/ survival in a non-cultural, purely physical register, we will be tempted immediately to go to the terrible facts of historical demography. The European invasion of the Americas brought catastrophe. For example, in what we now know as Peru, between 1520 and 1630 , the total Indian population fell from 3.3 million to 600,000 (Saignes, 1999: p. 87). In the first century of colonial penetration of the Paraguayan region, the Guarani population fell to one tenth of its estimated pre-invasion level (Garavaglia, 1999: p. 25). In the middle of the eighteenth century $(1730-1780)$, the Caribs were reduced from 120,000 to 20,000 (Whitehead, 1999: p. 399). Much of the New World mortality was due to diseases against which people had no immunity, and some of the most devastating epidemics arose when missionaries relocated peoples, the better to evangelize them (Whitehead, 1999: p. 399). What we know of New World population history puts us in mind of an irreducibly material sense of 'survival': millions of people did not live as long as they would have had they not been infected, shot at, persecuted or disrupted in their productive activities; some peoples were wiped out altogether, and others came close to total extinction. There is colonial testimony that in Andean regions, in the seventeenth century, women ceased to believe in the reproduction of their own kind, preferring to bear children from Spanish, Mestizo and even African men, so that their children would be spared labour service and tribute (Saignes, 1999: p. 93). Three centuries later, on a dejected Australian frontier, two anthropologists heard demographic despair among Gurindji women (Berndt and Berndt, 1987: pp. 90-91).

Nonetheless, today we refer to some of the peoples of Peru, Paraguay and Australia (and many other countries) as 'Indigenous'. We imply their 'survival' and their 'recovery', in the face of every adverse colonial circumstance. Thus Thornton dates the 'nadir' of the North American Indian population at 'around the turn of the twentieth century' (Thornton, 2002: p. 73). Any narrative of 'survival' and 'recovery' might seem to rest on facts that are simply biological, variables untroubled by culture, such as the ratio of males to females, the age structure, the average fertility and the ages of death. However, these are variable characteristics of something - a human population, or a 'people' - that is inescapably 'cultural', for a 'people' cannot be conceived independently of the criteria by which humans reckon themselves to be different kinds of humans - 'peoples'. To conceive of the survival and/or recovery of an Indigenous people, we must consider the social processes 
that constitute that category. In presenting Indigenous population figures for Bolivia, Brazil, Colombia, Ecuador, Paraguay, Pert and Venezuela, Maybury-Lewis explains that 'the question of who consider themselves (or are considered) to be indigenous is a highly ideological one' (Maybury-Lewis, 1999: p. 873; and see Pool, 1985). In what counts as 'Indigenous', public policy and popular culture engage. According to Thornton, in the USA "about 25 per cent of the population "growth" of American Indians from 1960 to 1970 , about 60 per cent of the "growth" from 1970 to 1980 , and about 35 per cent of the "growth" from 1980 to 1990 may be accounted for by ... changing identifications'. Like Maybury-Lewis, he speculates that the changing public value of being Indian has encouraged people to declare to the Census authorities that they are Indian (Thornton, 2002: p. 76). These acts of self-identification must be included in what Maybury-Lewis means when he refers to a people maintaining a sense of satisfactory continuity with the past. To declare oneself to be 'Indian' is to assert membership of a surviving people. However, in the USA and Canada, individual (or household head) self-identification is not the only way that the Indigenous "self" is enacted. The history of Indigenous relationships with the state, in those two nations, has given rise to supra-individual selves - tribes or bands - that are empowered to detemine who is 'Indian'. Thornton sees a trend that is fed by the persistent tendency of some city-dwelling peoples to identify as Indians and by Indians' high rates of marriage to non-Indians: 'A Native American population comprising primarily "old" Native Americans strongly attached to their tribes' may change to a "population with a predominance of "new" Native American individuals who may or may not have tribal attachments or even tribal identities' (Thomton, 2002: p. 80). Here is an excellent example of the difficulty of judging 'cultural survival'. If the Native American population continues to grow, but 'tribes' are less salient social forms, should we speak of cultural survival? Answers to this question will vary.
Although it is tempting to conclude that 'cultural survival' is a project without general criteria of success, within the UN's Human Rights Committee in the 1990 s there had been some consistency to Indigenous thinking. It had conceptualized 'culture as reproduced through and dependent on a resource base. that, if taken away, violates a group's capacity and right to exist collectively' (Muehlebach, 2003: p. 256). Even if political activism secures such a notion of "culture' as 'territorialized practice', in arguments with nation states about recognizing land rights, there remain opportunities for disagreement about the strategies for reproducing that practice. The Khanty of Siberia, for example, debate whether to accept payments from energy corporations, "with moralists arguing that [Khanty] leaders cannot effectively fight development if they are in the pay of administrators, who are in turn too cozy with energy company officials. Others argue that precisely energy money, in negotiated fixed percentages, should go toward cultural programs and infrastructure such as school, housing and clinics' (Balzer, 2003: p. 128). The Innu of Canada make diverse assessments of whether hunting and bush living are central to their survival.

\begin{abstract}
Some believe the Innu should live in the bush for extended periods of time and that this shoutd be supported by such things as rearranging schooling and setting up alcohol treatment centres in the bush .... Others, however, say that, while going to the bush should be an option, the practicalities of competing needs dictate that this cannot be expected of everyone and that, therefore, it camot be imposed. These people argue that innu culure can also be passed on within the village setting by modifying the school curriculum and through the use of radio and other media. (Tanner, 200 : pp. 408-409)
\end{abstract}

If the demography, the social forms, and the strategies of 'Indigenous cultural survival' are so resistant to general definition and formulation, is the plrase empty of meaning? One cannot easily set aside the terms in which human dignity is nowadays so effectively asserted. In the rest of this chapter, I want to build up an account of 'Indigenous cultural survival' that would cohere around the theme 
clude that ut general 's Human had been inking. It produced rce base, capacity ehlebach, activism as 'territh nation its, there ent about practice. e, debate energy ing that ly fight pay of oo cozy rs argue gotiated cultural school, p. 128). ssments ecentral

11s, and "rvival' on and aning? which ctively vant to ultural theme of 'managing exchanges'. I will review studies of three kinds of exchanges that indigenous peoples are trying to manage: the exchange of their labour power, the exchange of certain goods as 'art', and the political exchanges that are intrinsic to their emergence as a global movement.

\section{INDIGENOUS LABOUR POWER, CULTURE THROUGH SPACE AND TIME}

In 1971, the geographer Wilbur Zelinsky remarked that "The growth of human mobility has been spectacular in modernizing societies' (Zelinsky, 1971: p. 224). The two most important mobilities in modem history have been from countryside to city and from advanced' to less advanced regions of the world. Using 'mobility' broadly enough to make 'mobility' another summary term for modernity's dissolution of 'tradition', Zelinsky points to the spatial aspects of what Taylor, in his account of modernity, calls 'disembedding'. Zelinsky refers not only to spatial mobility, but also to mobility of mind '.. there remain no effective boundaries beyond which the nimbler mind cannot penetrate' (Zelinsky, 1971: p. 225). In Zelinsky's paper we can see an account of three processes that have given rise to contemporary Indigenous circumstances: the colonization of the lands and peoples of the New World by the peoples of Europe, the creation of national and global labour markets, and the rise of global tourism.

Human geographers and demographers have recently considered Zelinsky's relevance to Indigenous people in the settler colonial nations Australia, Canada, New Zealand and the USA - the Indigenous peoples that were largely responsible (with Saami and Inuit) for successfully initiating 'the indigenous voice in world politics' in the period 1975-1982 (Wilmer, 1993: pp. 137-138). As a condition and an effect of that voice, Indigenous leaders are now among those exemplary moderns who travel city-to-city (Oslo-Geneva-New York, for example), but I will leave until the last part of this chapter my discussion of the cultural consequences of that kind of Indigenous modernity. In this section I will confine myself to describing the evident ambivalence of Indigenous peoples towards labour markets in these four nations.

In Australia a relatively high proportion of the Indigenous population lives outside metropolitan areas, and a relatively high proportion of Indigenous mobility is circular, within region, and comparatively frequent, sustaining social and ceremonial networks and modified subsistence economy; in some regions, people have dispersed from small towns to live as family-based groups on their land (Taylor and Bell, 2004: pp. 15-17). This pattern of mobility is in a mutually reinforcing relationship with the high rates at which Indigenous Australians are unemployed and/or not looking for work (Taylor and Bell, 2004: p. 25). There is an apparent trend for Indigenous Australians to become increasingly urban, but this is less because people are leaving the rural and remote regions and more because it has become more common for metropolitan people of Indigenous descent to declare themselves Indigenous in the Census. Those who live some time in the metropolitan areas are comparatively likely to move between city/town and hinterland, rather than between cities, as non-Indigenous Australians do. As Taylor and Bell point out, we can describe this situation either as 'the lack of Indigenous integration with mainstream institutions' or (emphasizing Indigenous agency) as "an ongoing capacity of Indigenous people to sustain difference' (Taylor and Bell, 2004: p. 38).

Maori adapted to the British colonization of New Zealand by becoming farmers, encouraged by British policies and by their own leaders; their migrations to sell their labour were over short distances. For about a century, Maori remained very much within their regions of origin, their relative immobility securing continuity in their modes of employment (farming, forestry, fishing) and in their social life. Their population recovered to its 1840 level by 1945 , and eventually the opportunities of the cities began to attract them out of their viable but relatively static 
rural enclaves, particularly under the stimulus of World War II, with its opportunities for enlistment and manufacturing employment. From 1945 to 1971 , Maori massively relocated to the cities (they went from being 75 per cent rural to 75 per cent urban; Bedford and Pool, 2004: p. 61), and from rural to manufacturing occupations. Although a desire to participate in the wider economy motivated that shift, according to Barcham (2004: p. 165), urbanization did not extinguish Maoris' sense of cultural difference, for it was from among young urban Maori that a movement of cultural revival - uniting Maori from different regions - took off in the 1970 s. The 1975 Tieaty of Waitangi Act, establishing the Waitangi Tribunal, was one result. A new Maori intelligentsia became the interlocutor of government, as public policy devolved responsibilities for programmes to Maori organizations known as iwi. This official affirmation of Maori institutions, combined with the strong sense that Maori ways are ever at risk, has made it desirable for individual Maori to be both urban and rural, resulting in 'Maori return-migration'. According to Barcham. while this Indigenous habitus is at least partially dependent on labour market conditions', it also depends 'upon certain cultural factors', notably their relationship with 'their papa käinga (traditional tribal territonies)' (Barcham, 2004: p. 173). Returnmigration contributes to 're-tribalization'; it enables Maori to affirm their 'Maori side' (Barcham, 2004: p. 177).

In the USA, there are relatively high rates of population mobility among the Indigenous populations (Snipp, 2004: p. 197), but selling one's labour is only one reason to move. Snipp comments on US Indians' mobility from the point of view of cultural survival or as he says, of "sustaining and enhancing the cultural, political and economic viability of Indigenous communities' and of 'finding ways to transport and reproduce Native culture through space and time' (Snipp, 2004: p. 198). Thus, it is possible to consider Native American urbanization as a challenge to the principal institution of their society, the reserve-based tribe. Eschbach points to an apparent tension between the goals of raising Indians' material living standards and preserving reserve populations: "urbanizing out-migration as a development strategy seens to compromise the promise of tribal sovereignty' (Eschbach, 2004: p. 86). As in New Zealand, a significant proportion of Indians have become urban only since World War II. And, as in New Zealand, returnmigration has recently become a feature of Indian mobility, or so Snipp suspects (Snipp. 2004: p. 185). Snipp evokes the problem facing Native political leaders. On the one hand, they seek to preserve the connections between the more mobile Indians and their tribe/reservation of origin; this keeps the population estimates large (for govemment funding purposes), it secures the political and financial support of the mobile ones. and it keeps open the possibility that one day some of the best-trained Indians will work for their tribe. On the other hand, the return (or the coming and going) of Indians who have one foot in the city can be a disturbing influence even when they are long-time friends and family' (Snipp. 2004: p. 189). Governments deal with Indians as recognized tribes on reserves; it is not in the interest of reserve-based leaders to encourage governments to recognize and support 'urban tribes', though Indian Centres in some cities (Los Angeles, Oakland, Tulsa. Minneapolis) are able to help reservation Indians who migrate short-term to cities. Long-term migration to cities has gained employment and a materially improved life for some Indians, while posing to reserve leaders the issue: should they continue to be counted as members of the tribe? (Snipp. 2004: p. 193).

Canada's Indigenous people have been more mobile than the Canadian average in the second half of the twentieth century (according to recent analysis of the Canadian Census) and Registered Indians have been more mobile than other categories of Aboriginal Canadian (Norris et al., 2004: p. 1491. Observers expected in the 1960s that there would be net migration of Registered Indians from reserves to cities, as they searched 
for work and became more assimilated into the wider Canadian culture. The data since then contradict this scenario, with both cities and reserves gaining from Indian migration while non-reserves and smaller cities have lost Indians. Registered Indians tend to churn', that is, to move back and forth between their reserves and cities. They are pulled to cities by better opportunities for consumption and employment and by the need to widen their social and intellectual horizons; they are pulled back to the reserves by the cheaper housing, ties with family, and by services tailored to their legal and cultural status as Indians. A large part of the off-reserve (including cities) growth in Indian population has been an effect of legislative expansion of the definition of a Registered Indian. The factors promoting the increase in reserve populations include the benefits available to Registered Indians living on reserves. The 1991 Aboriginal Peoples Survey found that employment was a relatively unimportant stated motive for mobility (particularly for women) (Norris et al., 2004: pp. 152-153). Taking these findings together (and ignoring differences among reserves in their rates of out-migration and in-migration) the reserve-urban 'churning? mobility of Registered Indians can be interpreted as the expression of a persisting cultural difference, supported by government policies favouring Registered Indians and their adapted collective institutions, bands governing reserves.

In 1985, the Grand Council of the Crees told the UN's Working Group on Indigenous Populations that they wanted to have a choice between continuing a traditional life on the land, or participation in the new wage earning economy' (quoted in Niezen, 2000: p. 124). In the known mobility patterns of Indigenous people in Australia, Canada, New Zealand and the USA that choice is evidently being sustained, allowing a distinct Indigenous modernity. Their mobility is not actuated so much by the prospect of selling their labour at a high price, as it is by family and community strategies of social integration. Two kinds of public policy support this modernity: recognizing Indigenous community structures, and conceding an Indigenous land base.

However, it is possible that a third government policy - Census enumeration may modify the effect of the first two. To the extent that settler colonial nationalism now honours 'indigeneity' and to the extent that Censuses count people who identify as Indigenous, whether or not they have tribal or iwi affiliation, the Indigenous population of four nations has developed a core/periphery structure. In the USA, more than one third of those who meet Census criteria of Indian (that is, declare themselves to be Indian) are not tribal 'Indians' (Thornton, 2002: p. 79) either because they fail to meet criteria of tribal membership or because they did not seek a tribe's judgement on that matter. In Canada's 1996 Census, of 1.1 million people reporting Aboriginal ancestry, 799,000 reported themselves as members of a particular Aboriginal group or as registered under the Indian Act (Norris et al., 2004: pp. 137-138). Barchan (2004: p. 178) reports that 26 per cent of all individuals who identified as of Maori descent at the 1996 Census gave no iwi affiliation. In Australia, Indigenous respondents to the 2002 National Aboriginal and Torres Strait Islander Social Survey (NATSISS) showed marked regional variations in affiliation to the more traditional formations. Fewer than half ( 45.7 per cent) of the Indigenous people in cities, towns, agricultural and mining regions in Australia (where three out of four Indigenous Australians live) see themselves as belonging to a clan, tribal or language group. In 'remote' regions, where the other 25 per cent of Indigenous Australians live, three out of four people (76 per cent) identify themselves as part of a clan, tribal or language group (Australian Bureau of Statistics, 2004). In these four nations there is no necessary correspondence between participation in government-recognized Indigenous political institutions and enumerated (and self-proclaimed) Indigenous identity. Whether that is a challenge or a boon to 'Indigenous cultural survival' is a matter for debate. 


\section{THE RELEVANT MEANINGS OF INDIGENOUS ART}

Sustained by a mixture of welfare payments, hunting and gathering and artefact sales, and with secure land tenure and modern technologies of transport and communications, Aborigines of Australia's western desert maintain an extended 'moral community' (Peterson, 2004: p. 234) in which there are few opportunities (and arguably little need) to sell their labour power. Since about 1971, however, there have been increasing opportunities for these people to export goods that symbolize the foundations of that "moral community'.

The international social field in which they exchange these objects returns to the Pintupi not only money but also meaning and esteem; the sources of that money, meaning and esteem are various, and many are far (physically and culturally) from the western desert. Is this exchange securing or undermining the 'cultural survival' of the Pintupi? Closing his recent study of these transactions, Fred Myers remarks that "perhaps we understand the commodity and commoditization less well than we have presumed' (Myers, 2002: p. 361).

Myers credits the Australian government with good intentions towards the Pintupi. In the 1970 s, shortly after they began to paint for sale, it became government policy to purchase Pintupi paintings through two publicly funded agencies, for Pintupi aspirations to earn cash incomes far exceeded the early demand for their art. In a region that did not attract Australian enterprises, the government sought a 'culturally appropriate' economic base for the Pintupi; at the same time, the government recognized their customary possession of land, and it amended social security policy to make them eligible for unemployment and other benefits.

In the 1980 s, the governmental hopes for a western desert economy began to be answered as Australian and global demand for westem desert art soared. The relationship between two regines of value became an explicit concern of the Aboriginal arts industry.
Aboriginal and non-Aboriginal valuations were understood to be independent but convergent: some works could be of both high 'Aboriginal cultural value' and high 'Western aesthetic value' - with 'tourist art' ranking 'low' on both scales. As city-based public collections began to acquire 'good' paintings. a hesitant discourse of connoisseurship arose, sensitive to the cultural gap between the producers and the new consumers. Though connoisseurs tended to value westem desert art as a distinctly Australian episode in formalist modernism, rather than as referencing particular people/land relationships in a remote Australian region, the paintings "Aboriginality" was usually celebrated. Many Australians welcomed the assurance that past colonial policies had not destroyed all of Australia's 'Indigenous culture'. The artistic commissions for the new Australian Parliament House (which opened in 1988) included a huge ground mosaic by Michael Nelson Tjakamarra that gestured towards Australians' post-colonial maturity.

The painters' success provoked a discourse of Indigenous vulnerability. Some observers said that western desert peoples' problems and interests were being forgotten as the art's formal beauty and national significance overwhelmed public attention. Myers takes issue with commentators who fear that in attaining global artistic success the Pintupi have forfeited their 'distinctive voice' (Myers. 2002: p. 233). The reason he can portray the circulation of acrylic paintings as an extension of the agency of their makers, subject to varying responses and actions beyond their making' (Myers, 2002: p. 353) is that he adopts a performative notion of the paintings meanings. To render as a system the art's semantics is not possible, he argues: it is not so much that the paintings have meaning, it's more that the Pintupi deploy their meanings in a number of contexts in which those meanings have relevance. He refuses to privilege - as originary or definitive - those contexts that are local to the western desert (Myers, 2002: p. 53). From this theoretical position, the arrival in New York of westem desert art (and of some Pintupi artists) in 1988 can be told 
valuations ndent but f both high "Western t' ranking ed public paintings; hip arose; ween the . Though enn desert pisode in as referonships in paintings" ed. Many ince that destroyed are'. The ustralian in 1988) Michael towards

liscourse bservers roblems 1 as the nificance rs takes - that in Pintupi (Myers, tray "the xtension bject to nd their that he intings' he art's it is not ing, it's nings in eanings ge - as xts that 2002: on, the art (and be told as an Indigenous challenge to metropolitan habits of mind.

In presenting the 'relevance' (Myers, 2002: p. 237) of the 'Dreamings' exhibition in New Yorks Asia Society Galleries to the western desert : artists, Myers points out that the non-Aboriginal curators contextualized each object with ethnographic information in an effort "to acknowledge in the Western space of art what Aborigines assert about their objects' (Myers, 2002: p. 250). More important to Myers's thesis, however, is his presentation of two Pintupi artists' sand-painting performance in the Gallery in November 1988. Myers reports the stated satisfaction of the two artists that in their performance (and with the assistance of Myers and two other anthropologists who fielded the audience's questions) they had represented their 'country' (not Australia, but the western desert 'estates' of which the two artists are custodians).

And the audience's understandings? 'I think. no one really knows what "happened" on the stage," Myers admits, 'whether spiritual energy and danger were evoked or negotiated, or whether Aboriginal relations to place were securely signified" (Myers, 2002: p. 272). (And he later illustrates the variety of themes In critics' appreciation of the whole exhibition.) From one point of view, this admission of uncertainty could be enough to warrant a judgement of the event's superficiality, but Myers invites us to see the performance as an 'occasion of culture making' whose representational adequacy must not be gauged by reference to a concept of culture "as a structured given'. Myers here invokes recent studies of Indigenous expression (for examples Ginsburg, 2002; Turner, 2002) in order to assert that culture is 'an imperfect fiction that is ambiguously mediated by multiple and shifting discursive moments' (Myers, 2002: p. 275).

We are still developing our ways to interpret such data (these elicited meanings), writes Myers, just as we are at the beginnings of developing a critical language for the appreciation of contemporary Indigenous art. He has no doubt that a political opportunity has presented itself: 'The circulation of
Aboriginal fine art does not erase the tensions within which whites and blacks cohabit so much as it creates a sphere or forum for discussing what Aboriginality and Aboriginal identity might be in relation to whites' (Myers, 2002: p. 317). Though he distances himself from those apprehensive of Pintupi culture's global 'success', Myers also hesitates to offer criteria for judging the survival of a 'culture' whose ontology is so elusive that it is 'an imperfect fiction ... ambiguously mediated by multiple and shifting discursive moments' (Myers, 2000: p. 275). Rather than assume marketization to be the agent of cultural doom, Myers interprets the many newsworthy scandals (about authenticity, exploitation, copyright) of the Aboriginal art world as 'a significant moment in the conceptualization or institutionalization of cultural property' (Myers, 2002: p. 330). Objects so hybrid are bound to cause trouble. Myers would like the painters to avoid two related threats posed by the more free-booting market success of their art: their dislocation from their country, and the severing of their accountability to their kin and to their regional communities. The continuing production, in art, of Pintupi identity must have some practical-institutional roots, and Myers thinks that how dealers behave makes a difference. Myers' fruitful theoretical uncertainty about the effects of 'commoditization' thus arises not only from his refusal to delimit the pertinence of the paintings' unfolding meanings ('the question of what kind of objects these are has not been settled'; [Myers, 2002: p. 339]) but also from his appreciation that the institutions of the art market are now intimately part of Pintupi practices of cultural reproduction.

\section{INTERNATIONAL COLLABORATION}

The work of Indigenous cultural survival is not only local, but also international, and thus it requires collaboration with other Indigenous people and with the personnel of multilateral agencies. We may regard these collaborations as 'exchanges'. On scheduled occasions, such as meetings of the Working 
Group on Indigenous Populations, people tell their stories (some horrific, some celebratory) and are rewarded with political standing; people debate the wording of important public statements and formulate consensus by exchanging phrases, sentences and paragraphs - pushing here, conceding there. Their work since 1975 (when the World Council of Indigenous Peoples formed at Port Alberni, Vancouver) has built up an international community with a body of shared knowledge, rules of behaviour, and strategic goals' (Niezen, 2003: p. 205).

Because 'Indigenous rights' are conceived in these exchanges as an instance of 'human rights', this global community demands of each of its participating peoples that it account for itself in terms of human rights violated and honoured. According to Russell Barsh, in 1995 the Mikmaq people committed themselves to this way of accounting their circumstances when they formally acceded to the International Covenants of Human Rights. They thus performed a sovereign action (though under UN rules they report to treaty monitoring bodies as an NGO). As well, the Mikmaq Grand Council was addressing 'demands by Mikmaq women for greater accountability on the part of Mikmaq officials elected under Canada's Indian Act', and they hoped that 'such openness would focus greater critical attention on violations of Mikmaq rights by Canada' (Barsh, 1995: p. 36). Three levels of political exchange were thus enacted by the Mikmaq Grand Council's accession to the Covenants: with their own member's, with the Canadian domestic political debate about Indigenous rights, and with the multilateral agencies that monitor compliance with the Covenants.

The reproduction of Indigenous culture is not a straightforward matter when the instruments of multilateralism are seized as weapons for survival. Niezen spells out the tems of the exchange by which Indigenous people have gained a voice in the UN: 'To maintain its credibility the indigenous forum will have to include within its purview not only the urgent problems of racism, loss of land, industrial degradation, and state assaults upon identity and cultural integrity but also the human rights abuses perpetrated by indigenous peoples themselves' (Niezen, 2003: p. 117). The application of the human rights covenants to the internal affairs of Indigenous peoples has been controversial. Some have argued that it compromises 'self. determination', or that notions such as 'gender equality' are 'alien to Indigenous culture' (as reported by Barsh, 1995: p. 36). Niezen sees Indigenous peoples as being in a 'Weberian dilemma". To deal effectively with modenity. Indigenous peoples must adopt modern forms of authority: "there is no way to defend traditional societies without in some way transforming them - without, above all, taking on some of the trappings of bureaucracy and written law' (Niezen, 2003: p. 142). 'Human rights universalism,' he predicts. will 'bring about as much, or more, cultural change as protection' (Niezen, 2003: p. 143). Barsh believes that much of that change is already evident. As an effect of colonization (including certain forms of recognition) the traditional functions of kinship and older ideals of personal responsibility have been displaced. Indigenous societies have become 'more like the states that oppress them' (Barsh. 1995: p. 48). Some Indigenous peoples in Canada have invoked individual rights not to defend the tribal social order against interference', but selfishly: 'the right to private property, the right to disregard family and clan obligations, the right to accumulate personal wealth without paying taxes' (Barsh, 1995: p. 51). For this very reason, Barsh argues, Indigenous peoples must entrench "rights" as a weapon against these new concentrations of power among Indigenous peoples. " Rights" become a necessary part of the new social fabric as both a destructive and remedial argument' (Barsh, 1995: p. 51).

There is irony - perhaps Faustian tragedy in such accounts of the modern Indigenous political trade-off. However, if we reconsider. yet again, the question of who is vulnerable, it is possible to think of these binds as opportunities. The politics of gender and age within an Indigenous society may be activated when certain standards of human rights are invoked. 

erable, opporwithin $d$ when voked.
In the assessment of Bartholomew Dean, Amazonian indigenismo 'continues to conceal the endurance of systematic social distinctions (such as gender inequality) through its appeals to a putatively universal indigenous subjectivity ... the exclusions, restrictions, and ill treatment associated with women's lives in Amazonia are largely ignored by the indigenous rights movement" (Dean, 2003: pp. 234-235). If Indigenous peoples answer to human rights scrutiny of their own affairs, the idea of "vulnerability' becomes pertinent to distinctions among an Indigenous people. For girls growing up now in Amazonia, the modernist challenges of 'human rights' politics might be just what is needed.

\section{CONCLUSION}

Charles Taylor writes that modern humans have imagined themselves to be parties to a moral order in which rights, freedom and mutual benefit are "to be secured to all participants equally. Exactly what is meant by equality will vary, but that it must be affirmed in some form follows from the rejection of hierarchical order' (Taylor, 2004: p. 22). Starting in the eighteenth century as the 'inaginary' of social elites and activist groups, this self-understanding has since spread 'downward and outward' Taylor, 2004: p. 144). The rise of the notion of 'Indigenous' culture/people/society can be understood as one of the trajectories of 'redaction' by which the modern social maginary is becoming more extensively and intensively established. We can discem two steps in the 'Indigenous' redaction.

The first (which is not over) has been rooted in the conviction that development will give 'individuals and societies more control over their own destiny', as Joseph Stiglitz explained in his 1998 Raul Prebisch Lecture. Challenging 'traditional societies' that accept the world as it is', Stiglitz continued:

Development enriches the lives of individuals by widening their horizons and reducing their sense of isolation. It reduces the afflictions brought on by disease and poverty, not only increasing lifespans, but improving the vitality of life. (Stiglitz, 2001 : pp. 58-59)

The more liberal expression of this confident mission allows that such transformations are subject to (what I have called) the immanent temporalities of peoples; those peoples are 'vulnerable' to development to the extent that their immanent temporalities are ignored or overridden. One way to understand 'indigeneity" as an emergent political construct is to historicize the various ways that 'vulnerability' has been (and continues to be) imagined. I have traced some episodes - from the formulation of Article 22 of the Treaty of Versailles to the World Bank's 1991 account of the 'Indigenous' as a set of 'vulnerabilities'.

In the assertion of women's rights within the political forums of colonized peoples we see not only another episode in the magining of Indigenous vulnerability but also an example of what is possible in the second step in the redaction of the 'Indigenous' as an instance of the modem. This second step is very recent; it became visible only in the last quarter of the twentieth century as Indigenous entities gained political standing in world forums and in the jurisprudence and constitutional development of nation-states. This phase in the redaction of 'Indigenous' disperses the initiative for redaction to many local political elites who now wish to elaborate, in thought and practice, their own ways to be modem, including their own reckonings with 'human rights'.

Two features of Taylor's argument are significant here. First, he concedes that since 'modern social imaginaries have been differently refracted in the divergent media of the respective national histories' we should not expect 'a simple repetition of Western forms when these imaginaries are imposed on or adopted in other civilizations' (Taylor, 2004: p. 154). We can expect Indigenous modemities to differ, in some respects, from those that have allowed them certain spaces in which to grow. Second, in saying so little about the place of non-human species and the earth, oceans and atmosphere in 'modem social imaginaries', Taylor exemplifies a flaw in the 
modern social imaginary to which Indigenous thought has been sensitive. In the 1990s, Indigenous discourse highlighted 'nature': the dangerous relationships between humans and other species and between humans and their resources base (Muehlebach, 2001: p. 436). Thus, Taiaiake Alfred, searching for an Indigenous 'sovereignty' that is not contained within the opportunity structures of liberalized colonial policy, includes 'the sustainability of the earth' among Indigenous objectives. He sees ecological limits to the "natural law' humanism from which the modern social imaginaries grew. "The land was created by a power outside of lhuman beings, and a just relationship to that power must respect the fact that human beings did not have a hand in making the earth, therefore they have no right to dispose of it as they see fit' (Alfred, 2002: p. 470). Alfred's reference to 'a power outside of human beings' need not be understood as restoring the theodicies questioned by natural law. I prefer to see it as the Indigenous invitation (cast, let us note, in the language of 'rights') to consider human history through Darwin's pitiless eyes.

\section{REPERENCES}

Agrawal, A. (1995) 'Dismantling the divide between indigenous and scientific knowledget, Development and Change, 26: 413-439.

Agrawal, A. (1996) 'A sequel to the debate (2); a response to certain comments', Indigenous Knowledge and Development Monitor, http://www nuffic $\mathrm{nl/ciran/ikdm/4-2/articles/agrawal.html.}$

Agrawal, A. (2002) 'Indigenous knowledge and the politics of classification', International social Science Joumal, 54(173): 287-297.

Alfred, T. (2002) 'Sovereignty', in P.J. Deloria and N. Salisbury (eds), A Companion to American Indian History. Malden (MA): Blackwell Publishers, pp. 460-74.

Australian Bureau of Statistics (2004) National Aboriginal and Torres Strait Islander Social Survey 2002, ABS Cat 4714.0

Balzer, M.M. (2003) 'Hot and cold: interethnic relations in Siberia' in B. Dean and J.M. Levi (eds), pp. 112-141.
Barcham, M. (2004) 'The politics of Maori mobility' in J. Taylor and M. Bell (eds), pp. 163-183.

Barsh, R.L. (1995) 'indigenous peoples and the idea of individual human rights', Native Studies Review,
10(2): $35-55$.

Bedford, R. and Pool, I. (2004) 'Flirting with Zelinsky in Aotearoa/New Zealand: a Maori mobility transition', in J. Taylor and M. Bell (eds), pp. 44-74.

Benfer, R.A. Jr. and Furbee, L. (1996) 'A seque! to the debate (8): Can indigenous knowledge be brokered without scientific understanding of the community structure and distribution of that knowedge?', Indigenous Knowledge and Development Monitor, 4(2). http://www. nuffic.n//ciran/ikdm/4-1/ articles/agrawal.htm!

Berndt, C.H. and Berndt, R.M. (1987) End of an Era. Canberra: Aboriginal Studies Press.

Beteille, A. (1998) 'The idea of Indigenous people', Current Anthropology, 39(2): 187-191.

Bowen: J. (2000) 'Should we have a universal concept of "indigenous peoples" rights?', Anthropology Today,

Brokensha, D.W. (1996) 'Comments on article by Arun Agrawal', Indigenous Knowledge and Development Monitor, $4(1)$, http://www.nuffic.nl/ciran//kdm/4-1/
articles/agrawal.htm!,

Brolwer, I. (1996) 'A sequel to the debate $(12)^{\prime}$, Indigenous Knowledge and Development Monitor, 4(2), http:/Www nuffic.ni/ciran/ikdm/4-i/ articles/agrawal.html.

Colchester, M. (2002) 'Indigenous rights and the collective conscious', Anthropology Today, 18(1): 1-3.

Dean, B. (2003) 'At the margins of power: gender hierarchy and the politics of ethnic mobilisation among the Urarina', in B. Dean and J.M. Levi (eds), pp. 217-54.

Dean, B. and Levi, J.M. (2003) 'Introduction', in B. Dean and J.M. Levi (eds). At the Risk of Being Heard: Identity, Indigenous Rights, and Postcolonial States. Ann Arbor: University of Michigan Press, pp. 1-44.

Ellen, R., Parkes, P. and Bicker, A. (2000) 'Introduction' in R. Ellen, P. Parkes and A. Bicker (eds), Indigenous Environmental Knowledge and its Transformations: Critical Anthropological Perspectives. Amsterdam: Harwood Academic Publishers, pp. 1-33.

Eschbach, K. (2004) 'Migration and spatial distribution of American Indians in the twentieth century', in J. Taylor and M. Bell (eds), pp. 75-93.

Garavaglia, I.C. (1999) 'The crises and transformations of invaded societies: the La Plata Basin (1535-1650)', in F. Salomor and S.B. Schwartz (eds), pp. 1-58.

Giarelli, G. (1996) 'A sequel to the debate (4): broadening the debate: the Tharaka participatory action research project', Indigenous Knowledge and 
mobility' in

and the idea dies Review

h Zelinsky in transition ${ }^{\prime}$,

'A seque! owledge be ling of the that knowevelopment $/ \mathrm{ikdm} / 4-1 /$

of an Era.

15 people,

concept of ogy Today,

le by Arun velopment $\mathrm{kdm} / 4-1 /$

debate velopment $\mathrm{kdm} / 4-\mathrm{l} /$

he coller$1-3$

: gender bilisation evi (eds),

B. Dean

g Heard:

l States.

$1-44$.

iduction"

figenous

mations:

terdam:

ribution ury, in
Qevelopment Monitor, http:/Wmw.nuffic.n/ciran/ /kdm/4-2/articles/agrawal.html.

Gibberd, K. (1937) /LO: The Unregarded Revolution. London: J.M. Dent and Sons.

Gusburg, F. (2002) 'Screen memories: resignifying the raditional in indigenous media', in F.D. Ginsburg, LAbu-Lughod and B. Larkin (eds), Media Worlds: Anthropology on New Terrain. Berkeley. University of Calfornia Press, pp. 39-57.

1averkort, B. and Hiemstra, W. (1996) 'A sequel to the debate (5): COMPAS: Intercultural dialogue on cosmovisions and agricultural development', Indigenous Knowledge and Development Monitor.

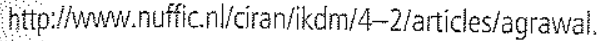
itml.

Helliwell, C. and Hindess, B. (1999) "Culture", "society" and the figure of man', History of the Human Sciences, 12(4): 1-20.

Hess, C.G. (1996) 'Comments on article by Arun Agrawal', Indigenous Knowledge and Development Monitor, 4(1). http:/Www.nuffic.nl/ciran//kdm/4-1/ articles/agrawal.html.

Heyd, T. (1996) 'Comments on article by Arun Agrawal', Indigenous Knowledge and Development Monitor, 4(1). http:/Www.nuffic.nl/ciran//kdm/4-1/ articles/agrawal.htm!

Hobson, JA. (1938) [1902] Imperialism: A Study. 3rd edn. London: Allen and Unwin.

International Labour Organization (1931) The International Labour Organization: The first Ten Years. London: George Allen and Unwin.

International Labour Organization 'C 107 Indigenous and Tribal Populations Convention 1957' http:/Www. ilo. orgiflolex/cgilex/convde.pl?C107>

lohnson, G. (2004) 'India and Henry Maine', in M. Hasan and N. Gupta (eds), India's Colonial Encounter: Essays in Memory of Eric Stokes. 2nd edn. New Delhi: Manohar, pp, 61-74.

Johnston, 8.R. and Garcia-Downing, C. (2004) 'Hydroelectric development on the Bio-Bio River, Chile: anthropology and human rights advocacy, in M. Blaser, H.A. Feit and G. McRae (eds), In The Way of Development. Indigenous Peoples, Life Projects and Globalization. London and New York: Zed Books, pp. 211-231.

Kenrick, J. and Lewis, J. (2004) 'Indigenous peoples' rights and the politics of the term "indigenous", Anthropology Today, 20(2): 4-9.

Kingsbury, B. (1998) " "Indigenous Peoples" in International Law: a constructivist approach to the Asian Controversy', American Jounal of International Law. 92(3): 414-457.

Köhter-Rollefson, I.U. (1996) 'Comments on article by Arun Agrawal', Indigenous Knowledge and
Development Monitor, $4(1)$. http://wmw nuffic.nl/ ciran/ikdm/4-1/articles/agrawa! html.

Kuper, A. (2003) 'The return of the native', Current Anthropology, 44(3): 389-402.

$\mathrm{Li}_{1}$ T. (2000) 'Articulating indigenous identity in Indonesia: resource politics and the triba! slot, Comparative Studies in Society and History, 42(1): 149-179.

Maybury-Lewis, D. (1999) 'Lowland peoples of the twentieth century', in F. Salomon and S.B. Schwartz (eds). The Cambridge Histony of the Native Peoples of the Americas vol, 3: South America Pt 2. Cambridge: Cambridge University Press, pp. 872-947.

Maybury-Lewis, D. (2003) 'From elimination to an uncertain future: changing policies toward indigenous Peoples', in B. Dean and J.M. Levi (eds), At the Risk of Being Heard: Identity, Indigenous Rights, and Postcolonial States. Ann Arbor: The University of Michigan Press, pp. 324-334.

Mclntosh, I. (2002) 'Defining oneself, and being defined as, indigenous', Anthropology Today, 18(3): 23-24.

Muehlebach, A. (2001) " "Making place" at the United Nations: Indigenous cultural politics and the UN working group on indigenous politics', Cultural Anthropology, 16 (3):415-448.

Muelehbach, A. (2003) What self in self-determination? Notes from the frontiers of transmational indigenous activism, ldentities: Global Studies in Culture and Power, 10(2), 241-268.

Murphy, C.N. (1994) International Organization and Industrial Change: Global Governance Since 1850. Cambridge UK: Polity.

Muthu, S. (2003) Enlightenment Against Empire. Princeton NJ: Princeton University Press.

Myers, F. (2002) Painting Culture: The Making of an Aboriginal High Art. Durham and London: Duke University Press.

Niezen, R. (2000) 'Recognising indigenism: Canadian unity and the international movement of Indigenous Peoples', Comparative Studies of Society and History, 42(1): 119-148.

Niezen, R. (2003) The Origins of Indigenism: Human Rights and the Politics of ldentity, Berkeley: University of California Press.

Norris, M.1., Cooke, M., Beavon, D., Guimond, E. and Clatworthy, S. (2004) 'Registered Indian mobility and migration in Canada: patterns and implications', in J. Taylor and M. Bell (eds), pp. 136-160.

Peterson, N. (2004) "Myth of the "walkabout": movement in the Aboriginal domain' in J. Taylor and M. Bell (eds), pp. 223-238.

Pool, I. (1985) 'The demography of indigenous minorities', in International Population Conference, Vol. 1 (Florence 5-12 June), pp. 135-141. 
Porter, B. (1990) 'Hobson and internationalism', in M. Freeden (ed.), Reappraising J.A. Hobson: Humanism and Welfare. London: Unwin Hyman, pp. 167-181.

Saignes, T. (1999) 'The colonial condition in the Wuechua-Aymara Heartiand (1570-1780)', in F. Salomon and S.B. Schwartz (eds), pp. 59-137.

Salomon, F. and Schwartz, S. (eds) (1999) Cambridge History of the Native Peoples of the Americas, Volume II, Part 1. New York: Cambridge University Press.

Semali, L.D. (1996) 'Conments on article by Arun Agrawal', Indigenous Knowledge and Development Monitor, 4(1). hittp://www nuffic.nl/ciran/ikdm/4-1/ articles/agrawal.html.

Serrano, R.C. (1996) 'Comments on article by Arun Agrawal', Indigenous Knowledge and Development Monitor, 4(1). htep:/www nuffic nl/ciran/ikdm/4-1/ articles/agrawal.htonl.

Snipp, C.M. (2004) 'American Indians and geographic mobility: some parameters of public policy', in J.Taylor and M. Bell (eds), pp. 184-200.

Stiglitz, J. (2001) 'Towards a new paradigm of development' (1998 Raul Prebisch Lecture), in Joseph Stiglitz and the World Bank: The Rebel Within Selected Speeches. London: Anthem Press.

Tanner, A. (2001) 'The double bind of Aboriginal self-government', in C.H. Scott (ed.), Aboriginal Autonomy and Development in Northem Quebec and Labrador. Vancouver and Toronto: UBC Press, pp. 396-4†4.

Taylor, C. (2004) Modem Social maginaries. Dumam and London: Duke University Press.

Taylor, J. and Bell, Mi, (2004) 'Continuity and change in Indigenous Australian population mobility', in J.Taylor and M. Bell (eds), Population Mobility and Indigenous Peoples in Australasia and North America. London and New York: Routledge, pp. 13-43.

Thornton, R. (2002) 'Health, disease and demography', in P.J. Deloria and N. Salisbury (eds), A Companion to American Indian History. Malden (MA): Blackwe! Publishers, pp. 68-84.

Turner, T. (2002) 'Representation, politics, and cultura! imagination in Indigenous video: genera! points and Kayapo examples', in F.D. Ginsburg, L. Abu-Lughod and B. Larkin (eds), Media Worlds: Anthropology on New Terrain. Berkeley: University of California Press, pp. 75-89.

Van Crowder, L. (1996) 'A secuel to the debate (3)', Indigenous Knowledge and Development Monitor, 4(2). http://wwwnuffic.nl/ciran/ikdm/4-1/ articles/agrawal.html.

van 't Hooft, K. (1996) 'Comments on article by Aruni Agrawal', Indigenous Knowledge and Development Monitor, $4(1)$, hitp://www nuffic.n//iran//kdm/4-1/ articles/agrawal.htm!.

Warren, D.M. (1996) 'Comments on article by Arum Agrawal', Indigenous Knowedge and Development Monitor, 4(1). http://wnw.nuffic n//ciran/ikdm/4-1/ articles/agrawal.html.

Warren, K.B. (1998) Indigenous Movements and their Critics: Pan-Maya Activism in Guatemala. Princeton: Princeton University Press.

Whitehead, N.L. (1999) Native peoples confront colonial regimes in northeastern South America', in F. Salomon and S.B. Schwartz (eds), pp. 382-442.

Williams, C.P. (1990) The ldeal of the Self-governing Church: A Study in Victorian Missionary Strategy. Leiden: E.J. Brill.

Wilmer, F. (1993) The Indigenous Voice in World Politics: Since Time Immemorial. Newbury Park: Sâge Publications.

World Bank (1991) 'Operational Directive: Indigenous Peoples' (OD 4.20) September. http://wblno018. worldbank.org/lnstitutional/Manuals/.

Yudice, G. (2003) The Expediency of Cuture: Uses of Culture in the Global Era. Durham and London: Duke University Press.

Zelinsky, W. (1971) 'The hypothesis of the mobility transition', Geographical Review, 6 f (2): $219-\cdots 249$. 


\section{The SAGE Handbook of \\ Cultural Analysis}

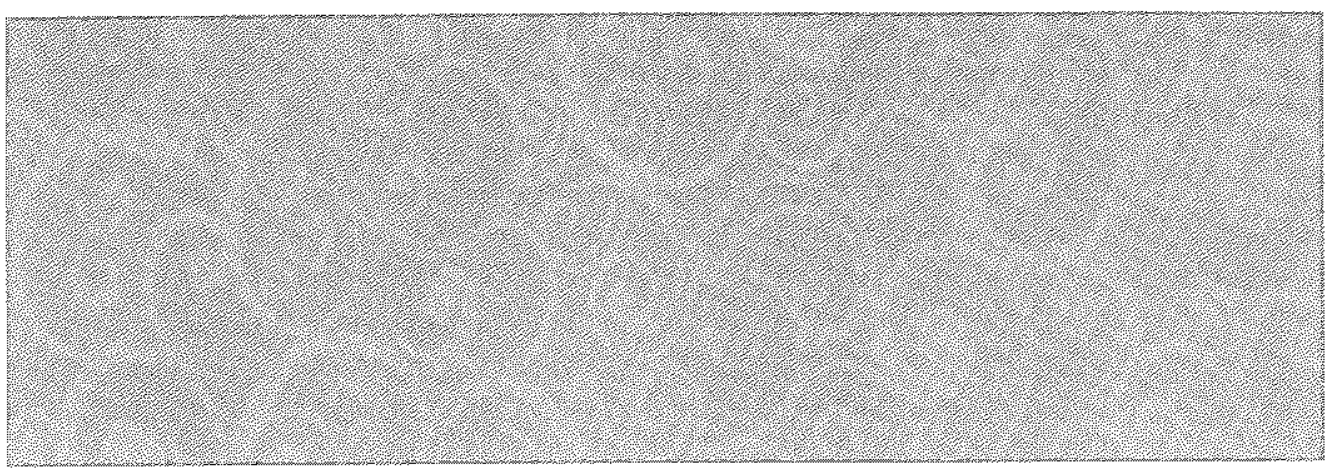

\section{Edited by Tony Bennett and John Frow}


$\rightarrow$ Editorial arrangement and introduction Tony Bennett and John Frow 2008

Chapters 1-25, 27-33 Sage Publications Ltd 2008

Chapter 26 @ David Hesmondhalgh 2008

First Published 2008

Apart from any fair dealing for the purposes of research or private study, or criticism or review, as permitted under the Copyright, Designs and Patents Act, 1988, this publication may be reproduced, stored or transmitted in any form, or by any means, only with the prior permission in writing of the publishers, or in the case of reprographic reproduction, in accordance with the terms of licences issued by the Copyright Licensing Agency. Enquiries concerning reproduction outside those terms should be sent to the publishers.

SAGE Publications Ltd

1 Oliver's Yard

55 City Road

London ECIY ISP

SAGE Publications Inc.

2455 Teller Road

Thousand Oaks, California 91320

SAGE Publications India Pvt Lid

B 1// 1 Mohan Cooperative Industrial Area

Mathura Road

New Delhi 110044

SAGE Publications Asia-Pacific Pte Ltd

33 Pekin Street \#02-01

Far East Square

Singapore 048763

\section{Library of Congress Control Number: 2007927716}

\section{British Library Cataloguing in Publication data}

A catalogue record for this book is ayailable from the British Library

ISBN $978-0-7619-4229-0$

Typeset by Cepha Imaging Pvt. Ltd., Bangalore, India

Printed in Great Britain by The Cromwell Press Ltd, Trowbridge, Wiltshire

Printed on paper from sustainable resources 


\section{Contents}

Acknowledgements $\quad \mathrm{v}$

Advisory Panel vi

Notes on Contributors $\quad$ vii

INTRODUCTION: VOCABULARIES OF CULTURE

PARTI FRAMEWORISS OF ANALYSIS

1 Anthropology and Culture $\quad 25$

Eric Gable and Richard Handler

2 Cultural Geography: An Account 46

Kay Anderson

3 Psychology and Cultural Analysis $\quad 66$

Valerie Walkerdine and Lisa Blackman

4 Sociology and Culture $\quad 86$

Tony Bennett

5 Cultural History $\quad 107$

Peter Burke

6 Literary Studies

126

James F. English

7 Culture and Music

Tia DeNora

8 Visual Analysis

Mieke Bal

9 Film Studies

Tom Gunning

10 Broadcasting

Toby Miller

11 Cultural Studies $\quad 227$

Ien Ang

12 Ferninism and Culture: Theoretical Perspectives 249

Griselda Pollock

13 Material Culture $\quad 271$

Daniel Miller

14 Culture: Science Studies and Technoscience 291 Andrew Pickering 


\section{PART II CURRENT ISSUES}

15 Culture and Nation

David McCrone

Joel S. Kahn

17 Globalization and Cultural Flows/Networks

Diana Crane

18 Colonialism and Culture

382

Christopher Pinney

19 Indigenous Culture: The Politics of Vulnerability and Survival

Tim Rowse

20 Cultural Property John Frow

21 Culture and Economy Timothy Mitchell

22 Culture, Class and Classification Mike Savage

23 Analysing Multiculturalism Today Ghassan Hage

24 Culture and Identity

Simon Clarke

25 Culture, Sex and Sexualities Elspeth Probyn and Gilbert Caluya

26 Cultural and Creative Industries David Hesmondhalgh

27 Cultural Technologies Celia Lury

28 Cyberculture and New Media Tiziana Terranova

\section{PART III RESEARCH THEORY AND PRACTICE}

29 Ethnography Johannes Fabian and Vincent de Rooij

30 Visual Anthropology Sarah Pink

31 Thinking by Numbers: Cultural Analysis and the Use of Data Justin Lewis

32 Discourse Analysis Lilie Chouliaraki

33 Cultural Activism Pepi Leistyna 
in The Netherlands, social and cultural dimensions of language contact, and the impact of new media on behaviour and cognition. Together with Johannes Fabian, he is the editor of the Langlage and Popular Culture in Africa (LPCA) web site (http:/www2.fing.uva.nl/lpca/).

Tim Rowse is in the History Program, Research School of Social Sciences, the Australian National University. Since the early 1980 s, his primary research and teaching interest has been in Australian Indigenous Studies, in particular: the colonial history of Central Australia; postWorld War II public policies towards Indigenous Australians; and Indigenous autobiography as a medium for Indigenous historical consciousness. His latest book (co-author Murray Goot) is Divided Nation? Indigenous Affairs and the Imagined Public (Melbourne University Publishing, 2007 ) - a study of public opinion polls and their place in the political process.

Mike Savage is Professor of Sociology at the University of Manchester, where he is convening Director of the ESRC Centre for Research on Socio-Cultural Change (CRESC). His interests lie in the intersections between studies in stratification and inequality, historical sociology, urban studies and cultural sociology. His recent books include Globalization and Belonging (with Gaynor Bagnall and Brian Longhurst, Sage, 2005), and Rethinking Class: Culture, Identities and Lifestyles (edited with Fiona Devine, Rosemary Crompton and John Scott, Macmillan, 2004). His book Discovering English Society 1950-2000: Popular Identities in the Social Science Imagination will be published by Clarendon during 2008.

Tiziana Terranova is Associate Professor in the Sociology of Cultural Processes at the Università degli Studi di Napoli, 'L'Orientale' under the sponsorship of the Italian Ministry of University and the Research Programme 'Rientro Cervelli'. She is the author of Corpi nella Rete (Costa and Nolan, 2006) and Network Culture: Politics for the Information Age (Pluto Press, 2004) and numerous essays on the cultural politics of new media.

Valerie Walkerdine is Professor of Psychology in the interdisciplinary social sciences in the School of Social Sciences in Cardiff University. She has worked on issues of subjectivity for many years, bringing together cultural and social theory witl critical psychology and psychoanalysis. Her latest book is Children, Gender; Videogames: Towards a Relational Approach to Multimedia (Palgrave, 2007). She is currently working on theoretical issues in connection with subjectivity and relationality, attempting to bring into dialogue notions of affect taken from social theory and object relations psychoanalysis. 